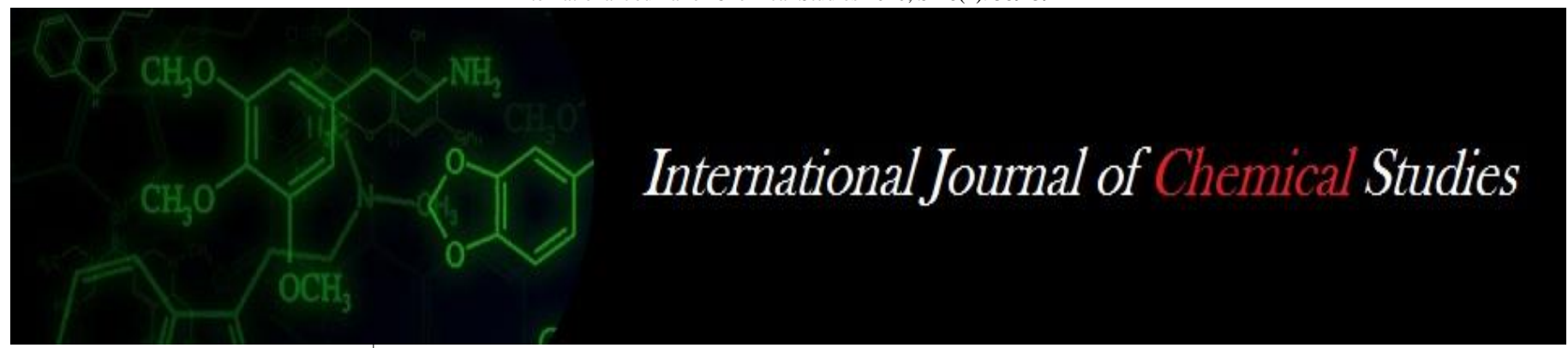

P-ISSN: 2349-8528

E-ISSN: 2321-4902

www.chemijournal.com

IJCS 2020; SP-8(4): 389-394

(C) 2020 IJCS

Received: 05-05-2020

Accepted: 09-06-2020

\section{S Yogaraj}

Department of Environmental

Science, Tamil Nadu

Agricultural University,

Coimbatore, Tamil Nadu, India

RM Jayabalakrishnan

Assistant Professor,

Environmental Science,

Department of Environmental

Science, Tamil Nadu

Agricultural University,

Coimbatore, Tamil Nadu, India

\section{Assessment of particulate matter deposition on tree species near Marudhamalai region}

\section{S Yogaraj and RM Jayabalakrishnan}

\author{
DOI: https://doi.org/10.22271/chemi.2020.v8.i4g.10122
}

\begin{abstract}
A survey of five dust polluted plants of different families Azadirachta indica, Pongamia pinnata, Ficus religiosa, Ficus benghalensis, Polyalthia longifolia were carried out in Marudhamalai Road, Coimbatore, India. The dust holding capacity of leaves, $\mathrm{pH}$ of dust wash of leaf surface and amount of total chlorophyll content with respect to dust deposition on leaves are determined. From the surveyed plants the quantity of dust deposition was recorded from the randomly sample leaves. The maximum dust deposition on leaf surface was recorded in Polyathia longifolia and minimum dust deposition was found on Ficus religiosa. The $\mathrm{pH}$ of leaf wash of dust was found maximum on dust polluted leaves as compared to the control. The minimum total chlorophyll content was recorded in dust affected leaves. The dust deposition may different according to the structure, area, roughness, hair growth in surface of leaves.

The dust may clogs pores of the stomata, it leads to change in respiration and transpiration process, no photosynthesis will occur and no food will be made hence tree will die off.
\end{abstract}

Keywords: Dust deposition on leaves, $\mathrm{pH}$ of leaves, Particulate matter on leaf dust

\section{Introduction}

In Coimbatore, Marudhamalai (11.04'E of longitude, 76.93 'N latitude and $426.72 \mathrm{~m} \mathrm{MSL}$ altitude) situated at Southern Western Ghats. Temperature begins increasing after March. April is hottest month with a near daily maximum temperature of $38.2^{\circ} \mathrm{C}$ and minimum of $25.6^{\circ} \mathrm{C}$. The maximum temperature may go up to $41^{\circ} \mathrm{C}$ and $16^{\circ} \mathrm{C}$, respectively. This area is occupied by many herbs, shrubs and trees. The amount of dust particles presents in the atmosphere causes air pollution. The dust present in the atmosphere is ultimately settle on ground and on vegetation. The dust is fine particle and particulate matter in the atmosphere. Dusts consists of solid matter in a minute and fine state of subdivision so that the particles are small enough to be raised and carried by wind. They may originate from many sources. A large range of industrial processes can produce particulate emissions (Fenelly, 1975) ${ }^{[13]}$. Dust particles emitting from different sources affects plant life in different ways. The plant exposed to heavy dust pollution shows variation according to the density of falling dust particles, the cover formed by deposition of dust particle decrease the pigment of plant leaves. The physical and chemical properties of plant tissue can also be changed by such large dust pollution. The dust deposition causes various effects on life activities of plants.

Plants are indispensable part of ecosystems and their sensitivity to air pollution is more considerable than standards of air pollution (Thomas, 1991) ${ }^{[47]}$. Air pollution has become a serious environmental stress to crop plants due to increasing industrialization and urbanization during the last few decades (Rajput and Agrawal, 2004) ${ }^{[32]}$. Diverse changes induced by different air pollutants in plants with respect to morphological, anatomical and physiological characteristics have been investigated (Rao, 1981; Pawar and Dubey, 1983; Rao and Dubey, 1988) ${ }^{[33,34]}$

The environment has reached its carrying capacity in terms of air pollutants like Nitrous Oxide (NOx), Sulfur dioxide $\left(\mathrm{SO}_{2}\right)$, Carbon Monoxide $(\mathrm{CO})$, Carbon dioxide $\left(\mathrm{CO}_{2}\right)$, Suspended particles and the toxic heavy metals like lead. Since, the major system and organs of plants are exposed to the atmosphere and the leaves continuously exchange gases in and out of the systems, any change in the atmosphere is reflected in the plant physiology. Thus, plants can be effectively used as bio indicators of air pollutants, although their sensitivities could vary across
S Yogaraj

Department of Environmenta

Science, Tamil Nadu

Agricultural University,

Coimbatore, Tamil Nadu, India 
the plant community with tolerant species showing no or minimal symptoms while sensitive ones showing symptoms even if the air pollutants increase in small amounts. Considering the role and effect of dust on plants, the present work is attempted to find out.

\section{Objectives}

1. To find out the effects of Dust Deposition on Plant leaves.

2. To analyze the $\mathrm{pH}$, Dust Holding Capacity and Chlorophyll content.

3. To evaluate how the dust changes / making trouble to the plant growth.

\section{Materials and Methods \\ Collection of sample}

Dust deposited fresh leaves of five tree species like Azadirachta indica, Pongamia pinnata, Ficus religiosa, Polyalthia longifolia were collected in the month of August 2019. Observations of selected plants were carried out for 8 to 10 days. The polluted leaves from top, middle and basal region of each plant was considered, collected and used for experimental analysis.

\section{Measurement of dust fall on the leaves}

Ten mature leaves of each sample plants were collected in a separate polythene bags. Leaves were collected at the height of three to four meters from all the sites. The measurement of dust fall was carried out by the method of Dry technique described by Das and Pattanayak (1997). In this technique at first the intact leaf was weighted (in $\mathrm{mg}$ ) and then dust particulates from leaf surfaces were gently collected with the help of camel hair brush and the weight of leaf was measured again. The amount of dust deposition in $\mathrm{mg} / \mathrm{cm}^{2}$ was calculated as per the following formula.

Dust content $\left(\mathrm{mg} / \mathrm{cm}^{2}\right)=\frac{\text { Weight of intact leaf }- \text { initial weight of leaf }}{\text { Total surface area of leaf }\left(\mathrm{cm}^{2}\right)}$

\section{Estimation of dust holding capacity}

The leaves of dust polluted plants were selected about three meters from the ground level. The sample of leaves were plucked off randomly from aerial part of the plant. Five samples of leaves were taken and average of it is considered. The leaves were brought in the laboratory and washed with distilled water. Suspension of dust were collected in petridish. The distilled water is then filtered using pre weighed filter paper and dust is collected. The weight of dust is noted after evaporation of moisture. The same weight is used to calculate dust holding capacity with the help of formula

Dust holding Capacity $\left(\mathrm{gm} / \mathrm{m}^{2}\right) /$ month $)=\frac{\text { Total weight of dust }}{\text { Total leaf area }} \times \frac{30}{\text { No of days of exposure }}$

\section{Determination of pH of dust}

A pinch of dust collected from both the surface of leaves were taken and added in that $5 \mathrm{ml}$ distilled water. The mixture is homogenized in a glass beaker. A broad range $\mathrm{pH}$ paper indicator is taken and dipped in the dust water suspension. The colour change of paper is matched with colour scale on a $\mathrm{pH}$ paper booklet. The $\mathrm{pH}$ values of each sample were compared and noted.

\section{Measurement of total chlorophyll}

The chlorophyll pigment of dust polluted leaves were estimated following the method of Arnon (1949) ${ }^{[2]}$. The fully expanded and dust deposited leaves from different sites of the Institutes campus were collected in the polythene bags and brought to the laboratory. The leaves were washed out thoroughly with distilled water. Three replicates were used for each plant. 01 gram leaf tissues of sample material was grinded, homogenized and extracted thrice in chilled $80 \%$ acetone $(\mathrm{v} / \mathrm{v})$. It was then centrifused at $5000 \mathrm{rpm}$ for five minutes and supernatant is made to $100 \mathrm{ml}$ by adding $80 \%$ acetone and the optical density was measured at $645 \mathrm{~nm}$ and $663 \mathrm{~nm}$ on a spectrophoto-meter.

\section{Result and Discussion}

The dust deposition on both the surface of leaves of different plants of different families were studied. Total five plants were sample (Table 1). The amount of deposition of dust found varied with respect to the size and texture of leaves.

The samples were surveyed and collected from Marudhamalai road, Coimbatore. The Dust Holding Capacity and hydrogen ion concentration and Chlorophyll content were recorded. A considerable variation regarding the results were found at different air polluted in marudhamalai road.

Table 1: List of Plant sample for dust deposition on leaf surface

\begin{tabular}{|c|c|c|}
\hline S. No. & Family & Scientific Name \\
\hline 1 & Meliaceae & Azadirachta indica \\
\hline 2 & Fabaceae & Pongamia pinnata \\
\hline 3 & Moraceae & Ficus religiosa \\
\hline 4 & Moraceae & Ficus benghalensis \\
\hline 5 & Annonaceae & Polyalthia longifolia \\
\hline
\end{tabular}

\section{Dust Holding Capacity (Table 2)}

From the observations recorded, it is clear that, the maximum dust holding capacity is found in Polyathia longifolia and Ficus benghalensis respectively. It may be due to the large surface area, texture of leaf surface for holding the maximum dust particles. In which he found maximum dust deposition on leaves having rough nature and presence of minute hairs on surface of leaves. The minimum dust deposition was found on leaf surface of Azadirachta indica, Pongamia pinnata, Ficus religiosa due to its minute, pinnate and smooth surface of leaves (Naik and Somasheker et al. 2006) ${ }^{[24]}$. Carried out the work on effects of dust fall on vegetation, according to their study dust pollution is important issue of ambient air.

\section{pH / Hydrogen ion Concentration (Table 3)}

The $\mathrm{pH}$ of surface dust deposited on the leaf surface were found maximum as compared to the control plants that were sparingly deposited by dust where amount of dust was very less in the area and that were very less deposited by dust particles. The change in the $\mathrm{pH}$ value may be due to moisture content held by deposited dust.

\section{Chlorophyll content (Table 4)}

The Maximum concentration of chlorophyll pigment found in the polluted plant Pongamia pinnata and minimum was recorded in Azadirachta indica, I found maximum number of chlorosis leaves in neem trees it may be records less chlorophyll content. The reduction in chlorophyll concentration in the polluted leaves could be due to chloroplast damage inhibition of chlorophyll synthesis. The dust particle affects plant leaves and ultimately affecting the photosynthesis and respiration. Dust can cause the leaf injury stomata damage, premature senescence and can decrease photosynthetic activity, disturb membrane permeability and 
reduce growth and yield in sensitive plant species. (Agrawal et al. 2006, Tiwari et al. 2006) ${ }^{[1,48]}$.

The capacity of leaves as dust receptors depends upon epidermal and cuticular features of leaves, surface geometry, phyllotaxy, type of canopy, leaf pubescence etc. The dust deposition not only depend upon the size and area of leaf surfaces but also the nature of leaf surfaces, thickness of leaf, orientation etc. which play an important role in the concentration of dust deposition and chlorophyll content. The photosynthetic pigment are the most likely to be damaged by air pollution. It may be because of the age of the leaf period of senescence, sensitivity of the plant species, biotic and abiotic condition and position of plant at the cross roads, suggest that high level of automobile pollution decreases chlorophyll content in higher plant near roadside (Gami and Patel, 2015) [14].

The study indicates that the total chlorophyll in control plants was always higher than that of the plants grown in dust polluted atmosphere. The reduction in yield may be attributed to the reduction in the photosynthetic pigments and the deposition of dust which leads to the clogging of stomata that interferes with gaseous exchange. The decrease in total chlorophyll content in unit fresh weight of polluted leaves might be due to chloroplast damage by incorporation of dust particulates into leaf tissue.

Increased dust deposition and subsequent reduction in chlorophyll may be positively correlated with reduced photosynthetic efficiency.

Table 2: List of plant sample and Dust Holding Capacity

\begin{tabular}{|c|c|c|c|}
\hline \multirow{2}{*}{$\begin{array}{c}\text { S. } \\
\text { No. }\end{array}$} & \multirow{2}{*}{ Scientific Name } & \multicolumn{2}{|c|}{$\begin{array}{c}\text { Dust Holding Capacity }\left(\mathbf{m g} / \mathbf{c m}^{2} \text { leaf }\right. \\
\text { Surface) }\end{array}$} \\
\cline { 3 - 4 } & & Control & Polluted \\
\hline 1 & Azadirachta indica & 00 & 0.683 \\
\hline 2 & Pongamia pinnata & 00 & 0.692 \\
\hline 3 & Ficus religiosa & 00 & 0.098 \\
\hline 4 & Ficus benghalensis & 00 & 0.788 \\
\hline 5 & $\begin{array}{c}\text { Polyalthia } \\
\text { longifolia }\end{array}$ & 00 & 1.355 \\
\hline
\end{tabular}

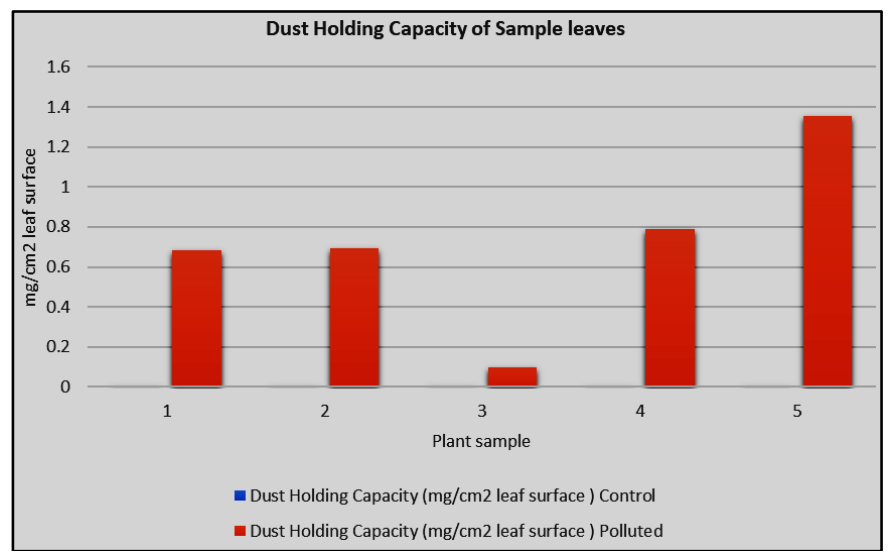

Fig 1: Plant sample and Dust Holding Capacity

Table 3: List of plant sample and $\mathrm{pH}$

\begin{tabular}{|c|c|c|c|}
\hline \multirow{2}{*}{ S. No. } & \multirow{2}{*}{ Scientific Name } & \multicolumn{2}{|c|}{$\mathbf{p H}$} \\
\cline { 3 - 4 } & & Control & Polluted \\
\hline 1 & Azadirachta indica & 8.2 & 8.7 \\
\hline 2 & Pongamia pinnata & 5.6 & 6.1 \\
\hline 3 & Ficus religiosa & 5.4 & 5.9 \\
\hline 4 & Ficus benghalensis & 6.1 & 6.6 \\
\hline 5 & Polyalthia longifolia & 6.4 & 7.3 \\
\hline
\end{tabular}

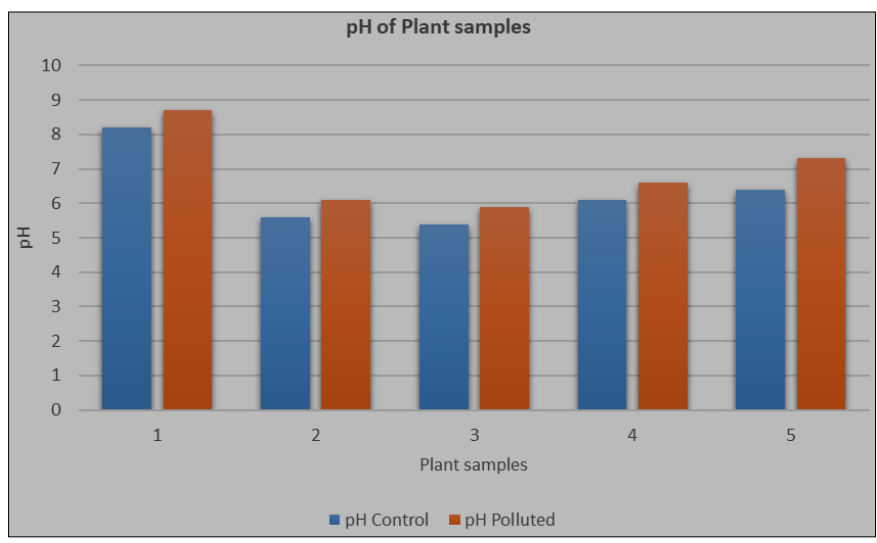

Fig 2: Plant sample and $\mathrm{pH}$

Table 4: List of plant sample and Chlorophyll

\begin{tabular}{|c|c|c|c|}
\hline \multirow{2}{*}{ S. No. } & \multirow{2}{*}{ Scientific Name } & \multicolumn{2}{|c|}{ Chlorophyll (mg/g fresh leaves) } \\
\cline { 3 - 4 } & & Control & Polluted \\
\hline 1 & Azadirachta indica & 0.13 & 0.09 \\
\hline 2 & Pongamia pinnata & 0.44 & 0.31 \\
\hline 3 & Ficus religiosa & 0.22 & 0.15 \\
\hline 4 & Ficus benghalensis & 0.29 & 0.22 \\
\hline 5 & Polyalthia longifolia & 0.34 & 0.21 \\
\hline
\end{tabular}

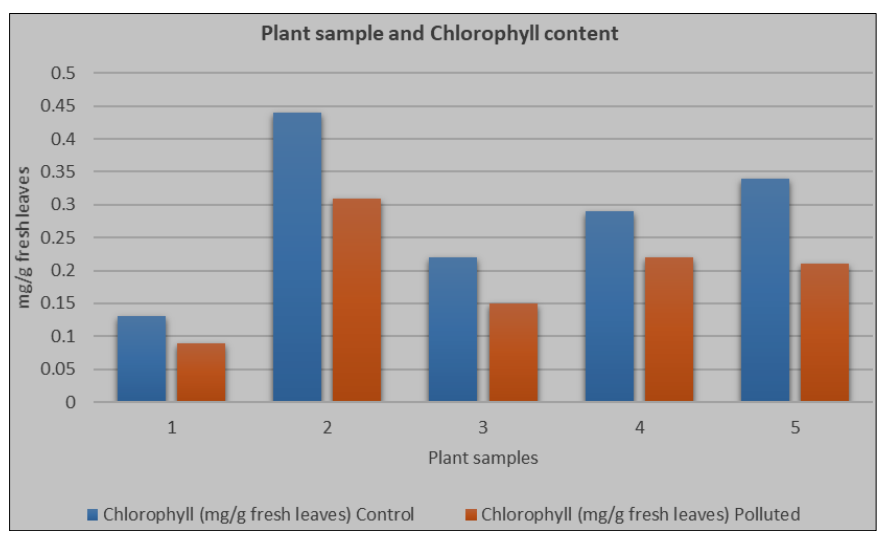

Fig 3: Plant sample and Chlorophyll content

\section{Summary and Conclusion}

The project aimed to investigate particulate matters and dust deposition on the leaf surface of five species Azadirachta indica, Pongamia pinnata, Ficus religiosa, Ficus benghalensis, Polyalthia longifolia these trees are most common on road sides so I took survey on it.

I analyzed Dust Holding Capacity of leaves maximum dust deposition is recorded in Polyalthia longifolia and minimum dust deposition recorded in Ficus religiosa, dust is formed by minute soil particles, particulate matters $\left(\mathrm{PM}_{2.5}, \mathrm{PM}_{10}\right)$, petrol chemicals which is oily in deposition which cause severe destruction of plant tissue and that oily nature increase in dust grabbing ability. Atmospheric dust accumulation varies with structure, geometry, height, size of petiole, presence/absence of hairs and presence of wax on leaf surface of selected plants. Plants with waxy coating, rough surface with folded margin accumulate more dust than plants with smooth, flat surface without folded margin.

Dust depositions induce changes in the biochemical parameters by increasing and decreasing their level in the plant leaves. It is revealed that the exposure to particulate deposition may alter plant growth and their production even though there may or may not be any marked physical damage to the plant. 
In $\mathrm{pH}$ analyzation the average of 0.5 variation in all the tree species except Polyalthia longifolia polluted $\mathrm{pH}$ is 7.3 and in controlled environment 6.4 , this may occured due to more dust deposition in it or its leaves are vertically arranged may not washed off in rain water.

In chlorophyll analyzation concentration is less in Polyalthia longifolia it may occurred due to more particulate matter and dust particles block the pores of stomata, stomata is the main organ in plants which helps the exchanging of oxygen and carbon dioxide, without the routine exchange how could the leaf produce the chlorophyll.

The protection of healthy environment is an important issue. The rapid deforestation and loss of vegetation helps to damage healthy environment as well as natural resources. The vegetation and forests are very important to balance the ecosystem.

To minimize the particulate matter deposition:

- $\quad$ Reducing the traffic: Vehicles traveling on roads stir up dust. Reducing the number of vehicles can reduce dust. Traffic can be reduced voluntarily; encouraging walking, cycling way. Traffic can be reduced by restricting vehicle weight or type, or by limiting motor vehicle access to dirt roads.

- $\quad$ Reducing the Speed: Fast moving vehicles stir up dust. Studies show that $\mathrm{PM}_{10}$, or dust, goes up with vehicle speed. Reducing speed from $40 \mathrm{kmph}$ to $20 \mathrm{kmph}$ reduces dust emissions by $65 \%$. Speed limit signs and enforcement can reduce speeds. speed bumps can reduce speeds. The effectiveness of speed limits depends on law enforcement and community willingness to abide by the rules. Speed bumps will only reduce dust close by improving road design.

- Reduce exposed ground: Covered ground doesn't blow away and create dust. Each dirt parking area, footpath, shortcut, or eroding bluff can produce dust. Every new trail makes the problem worse. Maintaining the native vegetation, woodland; replanting barren areas; planting gardens; and just driving only on designated roads or trails can all be dust control measures. Living plants not only cover the ground, but their roots hold soil together as well.

- Covering the exposed ground by lawn: Healthy lawns and other landscape plants contribute to improved air quality by acting as traps for dust and other airborne particles. Because a lawn completely covers a soil surface, soil particles are prevented from blowing around and being carried to another area.

- Recycling clippings by mulching and leaving on the lawn to decompose decreases the amount of carbon released into the atmosphere by 11 to 59 percent over removing clippings.

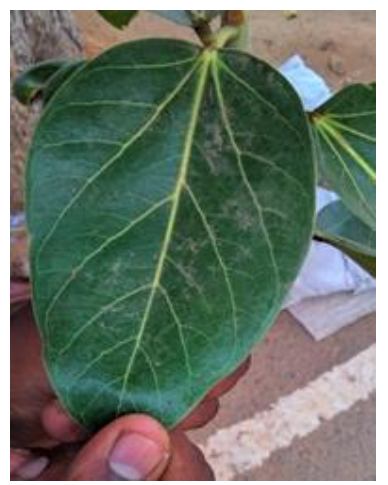

Plate 1: Dust deposition on Ficus benghalensis

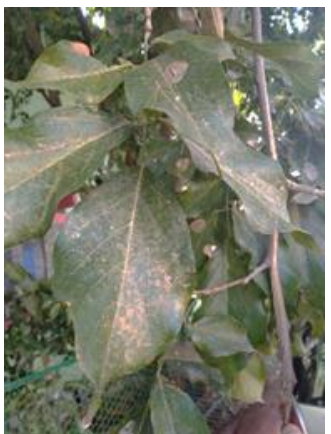

Plate 2: Dust deposition on Pongamia pinnata

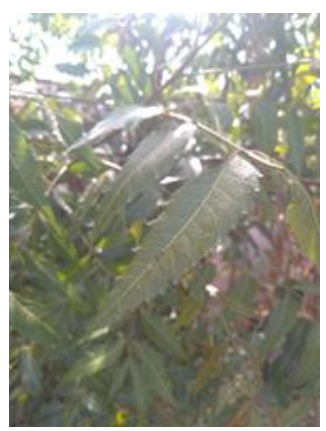

Plate 3: Dust deposition on Azadirachta indica

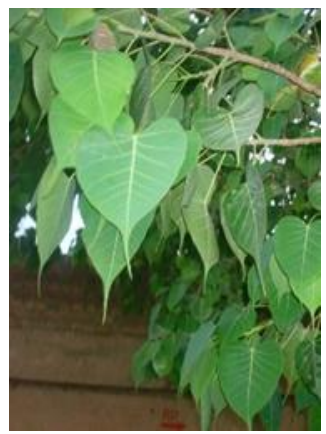

Plate 4: Dust deposition on Ficus religiosa

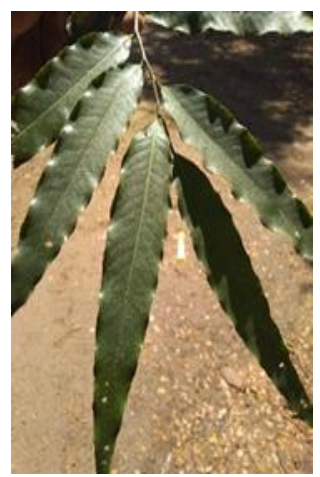

Plate 5: Dust deposition on Polyalthia longifolia

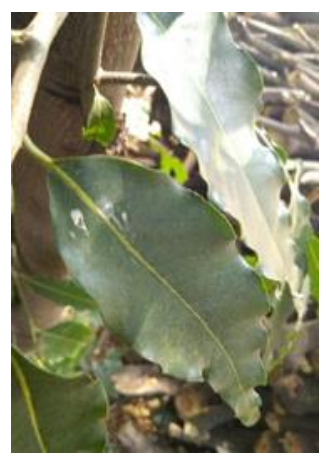

Plate 6: Dust deposition on Polyalthia longifolia 


\section{References}

1. Agrawal M, Singh B, Agrawal SB, Bell JNB, Marshall F. The effect of air pollution on yield and quality of mungbean grown in periurban areas of Varanasi. In: Water Air Soil Pollut. 2006; 169:239-254.

2. Arnon DI. Copper enzyme in isolated chloroplasts, ployphenoloxidase in Beta vulgaris. In: Plant Physiol. $1949 ; 24: 1-15$.

3. Abbasi S, Chari A, Gajalakshmi KB, Ramesh EB. Ramasamy: Approaches to greenbelt design. J. Inst. Pub. Hlth. Engi. 2004; 3:42-49.

4. Agarwal AL. Air pollution control studies and impact assessment of stack and fugitive emissions from CCI Akaltara cement factory. Project Report, Project sponsored by M/s. CCI Akaltara Cement Factory. NEERI Nagpur, 1988.

5. Agrawal S, Tiwari SL. Susceptibility level of few plants on the basis of air pollution tolerance index. Indian Forester. 1997; 123:319-322.

6. Arnon DI. Copper enzymes in isolated chloroplasts polyphenol oxidase in Beta vulgaris. Plant Physiol. 1949; 24:1-15.

7. Auerbach NA, Walker MD, Walker DA. Effects of roadside disturbance on substrate and vegetation properties in Arctic tundra. Ecol. Appl. 1997; 7:218-235.

8. Bendre AM. Practical botany, Rastogy publication, Merrut, India. First edition, 2007-2008, 69-71.

9. Barrs HD, Weatherly PE. A reexamination of the relative turgidity technique for estimating water deficit in leaves. Aust. J Biol. Sci. 1962; 15:413-428.

10. Conklin PL. Recent advances in the role and biosynthesis of ascorbic acid in plants. Plant Cell Enviro., CPCB: Guidelines for developing greenbelts. CPCB publication, programme objective series, PROBES/75. 1996-20002001; 24:383-394.

11. Dedio W. Water relations in wheat leaves as screening test for drought resistance. Canadian J. Plant Sci. 1975; 55:369-378.

12. Escobedo FJ, Wagner JE, Nowak DJ. Analyzing the cost effectiveness of Santiago, Chile's policy of using urban forests to improve air quality. J in vitro. Manage. 2008; 86:148-157.

13. Fennelly PF. Primary and secondary particulates as pollutants. In: J. Air Pollut. Contr. Assoc. 1975; 25:697704.

14. Gami AH, Patel NK. Comparing study of marble dust fall and examine chlorophyll content in various seasons of vegetation of Danta taluka. In: International research Journal of chemistry (IRJC) ISSN 2321- 2845, 2015, 2321-3299.

15. Gupta R, Chaudhari B, Wate SR. Overview on attenuation of industrial air pollution by greenbelt. J Indus. Poll. Con. 2008; 24:1-8.

16. Irwe RR, Sontakke SG, Sheikh SI, Darade MS. Study of dust deposition on leaves of some plant species in GVISH. Campus of Amravati (MS) India Int. J. of Life Sciences. 2017; 5(4):639-643. ISSN: 2320-7817, eISSN: 2320-964X

17. Katiyar V, Dubey PS. Sulphur dioxide sensitivity on two stage of leaf development in a few tropical tree species. Ind. J Environ. Toxicol. 2001; 11:78-81.

18. Katiyar V, Dubey PS. Growth behavior of two cultivars of maize in response to SO2 and NO2. J Environ. Biol. 2000; 21:317-323.
19. Klumpp A, Ansel W, Klumpp G. European Network for the assessment of air quality by the use of bioindicator plants, Report by University of Hohenheim. Ecomed Publishers, D-86899, Landsberg, Germany, 2003.

20. Liu Y, Ding H. Variation in air pollution tolerance index of plants near asteel factory: Implications for landscapeplant species selection forindustrial areas. WSEAS Trans. Environ. Develop. 2008; 4:24-32.

21. Mishra PN, Mishra AK, Williams AJ, Dugays D, Banerjee SK. Biological reclamation of fly ash forest plantations. In: Env. Ecol. 1995; 13:11-13.

22. Mashitha PM, Pies VL. Biomonitoring of air pollution by correct the pollution tolerance index of some commonly ground trees of urban area. Pollut. Res. 2001; 20:195197.

23. Ninave SY, Chaudhri PR, Gajghate DG, Tarar JL. Foliarbio chemical features of plants as indicators of air pollution. Bull. Enviro. Contam. Toxicol. 2001; 67:133140.

24. Naik DP, Ushamalini, Somashekar RR Dust pollution monitoring in stone Quarry area-A case study narasapura ko- lar district, Karnataka. In: J of Industrial pollution control. 2006; 22(2):357 360.

25. Pandey DD, Kumar S. Impact of cement dust pollution on biomass, chloph roll, nutrients and grain characters of wheat. In: Environ \& Ecology. 1996; 14:872-875.

26. Pawar K, Dubey PS. Effect of atmospheric pollutant on the morphology and pigment content in proceeding of sixth world congress on air quality. In: Paris. 1983; 2:501-50.

27. Radhapriya P, NavaneethaGopalakrishnan A, Malini P, Ramachandran A. Assessment of air pollution tolerance levels of selected plants around cement industry, Coimbatore, India In: J. Environ. Biol. 2012; 33:635-641. ISSN: 0254-8704 CODEN: JEBIDP

28. Pasqualini S, Batini P, Ederli L. Effects of short-term ozone fumigation on tobacco plants: Response of the scavenging system and expression of the glutathione reductase. Plant Cell Environ. 2001; 24:245-252.

29. Prajapati SK, Tripathi BD. Seasonal variation of leaf dust accumulation and pigment content in plant species exposed to urban particulatespollution. J Environ. Quality. 2008; 37:865-870.

30. Priyanka C, Dibyendu B. Biomonitoring of air quality in the industrial town of Asansol using the air pollution tolerance index approach. Res. J Chem. Environ. 2009; 13:46-51.

31. Qadir N, Quereshi RH, Ahamad N. Reclamation of saline sodic soil by gysono and leptochlora fusca. In: Geoderma. 1997; 74:204-217.

32. Rajput M, Agrawal M. Physiological and yield responses of pea plants to ambient air pollution. In: Indian J. Plant Physiol. 2004; 9:9-14.

33. Rao DN. Phytomonitoring of air pollution.: In Osmania University, Hyderabad, WHO workshop on biological indicator and indices of Environmental Pollution, 1981, $1-8$.

34. Rao MV, Dubey PS. Plant response against SO2 in field conditions. In: Asian Environ. 1988; 10:1-9.

35. Singh SN, Rao DN. Possibilities of using chlorophyll and potassium contents in plant to direct cement dust pollution. In: Indian. J Environ. 1978; 20:10-13.

36. Supe NG, Gawande MS. Effect of dustfall on vegetation. In: International Journal of Science and Research (IJSR), 2013. ISSN(online):2319-7064. 
37. Rawat JS, Banerjee SP. Urban forestry for improvement of environment. J Energy Enviro. Monit. 1996; 12:109116.

38. Sadasivam S, Manickam A. Biochemical methods. 2nd Edn. New age International Publishers, New Delhi, 1996.

39. Singh SK. Phytomonitoring of urban industrial pollution: A new approach. Env. Moni. Assess. 2003; 24:27-34.

40. Singh SK, Rao DN. Evaluation of plants for their tolerance to air pollution. In: Proceedings of symposium on air pollution control. Ind. Asso. Air Pollut. Con., New Delhi, 1983, 218-224.

41. Shrivastava N, Joshi S. Effect of automobile air pollution on the growth of some plants at Kota. Geobios. 2002; 29:281-282.

42. Swiercz A. Suitability of fine bark to evaluate pollution caused by cement-lime dust. J Forest Sci. 2006; 52:93-98.

43. Trivedi ML, Singh RS. Reduction in protein contents in a few plants as indicators of air pollution. Pollut. Res. 1995; 14:269-273.

44. Trivedi, Raman. Greenbelts for air pollution control. Indus. Pollu. Enviro. Manag., 2001, 121-129.

45. Tripathi AK, Gautam M. Biochemical parameters of plants as indicators of air pollution. J Environ. Biol. 2007; 28:127-132.

46. Tripathi AK, Tiwari PB, Mahima, Singh D. Assessment of air pollution tolerance index of some trees in Moradabad city, India. J Enviro. Biol. 2009; 30:545-550.

47. Thomas H. Accumulation and consumption of solutes in swards of Lolium perenne during drought and after rewatering. In: New Phytol. 1991; 118:35-48.

48. Tiwari S, Agrawal M, Marshall FM. Evaluation of ambient air pollution impact on carrot plants at a sub urban site using open top chambers. In: Environ. Monit. Assess. 2006; 119:15-30.

49. Vardaka E, Cook CM, Lanaras T, Sgardelis SP, Pantis JD. Effect of dust from a limestone quarry on the photosynthesis of Quercus coc cifera, and evergreen sc lerophyllous shrub. Bull. Enviro. Contam. Toxicol. 1995; 54:414-419.

50. Varshney CK. Buffering capacity of trees growing near a coal-fired thermal power station. In: Tropical ecosystems: Ecology and Management (Eds.: K.P. Singh and J.S. Singh). Wiley Eastern Ltd., New Delhim, 1992. 